\title{
Aineeton pääoma puhuttelee
}

Taru Rastas ja Virpi

Einola-Pekkinen (2001).

Arvoa aineettomasta

pää o m a s t a .

TAMMI

Aineettomasta, inhimillisestä tai sosiaalisesta pääomasta on viime vuosina keskusteltu niin yhteiskuntaa koossa pitävänä voimana kuin huomiotta jääneenä taloutta pyörittävänä rattaana. Keskustelu hyvinvointivaltion tulevaisuudesta on saanut huomion kiinnittymään alueille, joiden toivotaan pehmentävän harjoitetun kovan talouspolitiikan vaikutuksia (lähtökohtaisesti 'hyväksi' määritelty yhteisö tai kansalaisyhteiskunta). Kai Ilmosen mukaan (2000) instituutioiden legitiimiys on 1990-luvun ollut kovalla koetuksella. Kun usko poliittisiin puolueisiin on hapertunut, puolueet ovat alkaneet esittää paluuta perheeseen ja hyvään yhteisöllisyyteen.

\section{Robert Putnam vertasi} tunnetussa tutkimuksessaan Pohjois- ja Etelä-Italian taloutta ja politiikkaa. Hän päätyi siihen, että juuri sosiaalinen pääoma selittää pohjoisen ja etelän erot niin taloudessa kuin hallinnossa ja demokratian toimivuudessa. Vailla yleistä, outoihinkin kohdistuvaa luottamusta ei ole syytä luottaa kehenkään muuhun kuin oman klaanin jäseniin. Toimintatapa on rationaalinen lyhyellä aikavälillä, koska muut toimivat samoin. Näin kuitenkin talouden, hallintokoneiston ja demokratian luotettava toiminta estyy (Putnam 1993).
Yhteiskunnan ja talouden kitiksi nähtyä sosiaalista pääomaa voi vähentää paitsi perinteinen klaani- ja sukujärjestelmä, myös liian innokas luottamuksen siteiden purkaminen. Myös markkinat ovat instituutio, jolla on omat yhteiskunnalliset, oikeudelliset ja moraaliset ennakkoehtonsa (Lash 1994). Kun individualistinen rationaalisen valinnan teoria (kaikki yksilöt toimivat rationaalisesti ja tekevät samantyyppisiä valintoja hyvin informoituina) korvasi keynesläisyyden, tällä yksinkertaistavalla ja epärealistisella lähtökohdalla on Ben Finen (2001) mukaan ollut dramaattisia yhteiskunnallisia ja makrotaloudellisia vaikutuksia.

\section{Suursijoittaja Georg Soros} on varoittanut pitkällä aikavälillä tuhoisasta uusli-

beralismista. Hänen mukaansa nykymuotoinen globalisaatio johtaa yhteiskunnalliseen sekasortoon. Myös amerikkalainen taloustieteilijä Karl Polanyi (1944) katsoi, että saadessaan toimia vapaasti markkinamylly (tai runoilija William Blaken sanoin saatanallinen mylly) jauhaa sokeasti hajalle yhteiskunnan, joka myllyn on pystyttänyt.

\section{Myös yksityisissä ja} julkisissa organisaatioissa aineettomat alueet (luottamus, henkilöstön sitoutuminen, ympäristö- ja eettiset arvot, asiakastyytyväisyys jne.) on havaittu menestyksellisen toiminnan ehdoksi, mutta niiden arvoa on vaikea ilmaista rahallisesti.Arvoa aineettomasta pääomasta -teoksessa vain lyhy- esti sivuttu henkilöstötilinpäätös (ks. Ahonen 2000) on nähty yhdeksi keinoksi mitata organisaation aineetonta, henkilöstön kantamaa pääomaa.

\section{Vaikka monella suur-} yrityksellä on jo ympäristöohjelma, ei yksikään ole vielä julkisesti sitoutunut esimerkiksi YK:n Ihmisoikeuksien julistukseen. Arvojen ja visioiden julistaminen vailla yhteyttä arkeen on koettu riittämättömäksi. Liitenin (2002) mukaan amerikkalaisen energiajätti Enronin kotisivuilleet kirjaamat arvot ovat: kunnioitus, rehellisyys, kommunikaatiojaerinomaisuus.

Kansalais- ja työmarkkinajärjestöjen sekä elinkeinoelämän ja kirkon muodostaman eettisen foorumin tarkoituksena on luoda keskustelufoorumi, jossa luotaisiin yritystoiminnan eettiset ohjeet. Kuvajan (2002) mukaan foorumista voisi kehittyä uudenlainen vuorovaikutuksen kanava ja oppimisprosessi. Yrityksissä on myös valmiutta uudenlaisiin näkökulmiin. Keskuskauppakamarin Yrityskulttuuri-selvityksen (2001) mukaan noin $95 \%$ suomalaisyrityksistä ilmoittaa asettavansa toiminnalleen vapaaehtoisesti eettisiä normeja, jotka ylittävät lain asettamat velvoitteet. Yleisimmin vapaaehtoisia velvoitteita käytetään henkilöstön hyvinvoinnin lisäämiseksi (85 \%), asiakaspalvelussa $(67 \%)$, harmaan talouden torjunnassa (66\%) ja sponsorointi- ja lahjoituskäytännöissä $(64 \%)$. Selvityksen mukaan suurin osa $(85 \%)$ 
yritysjohtajista kannatti velvoitteiden vapaaehtoista lisäämistä.

Lukija joutuu pettymään, jos hän odottaa, että Taru Rastaan ja Virpi Einola-Pekkisenteos Arvoa aineettomasta pääomasta kertoisi organisaatioiden heräämisestä kantamaan eettistä ja yhteiskunnallista vastuutaan. Teos käsittelee liiketalouden ja johtamisen perinteistä kovaa ydintä, juuri sitä aluetta, jonka puhetapa on muuttunut "luonnolliseksi" myös julkisissa organisaatioissa ja osin jopa taiteen ja kulttuurin alueella: lehtitietojen mukaan Radion kamarikuoron johtaja kehui 40 vuotta täyttänyttä kuoroaan "osaavaksi, nopeaksi ja joustavaksi"!

Arvoa aineettomasta pääomasta -kirjan toinen kirjoittaja Taru Rastas on koulutukseltaan ekonomisti ja työskentelee tutkijana KTM:ssä. Virpi Einola-Pekkinen on kasvatustieteilijä, ja esittelyn mukaan tulokulma aineettomaan pääomaan on organisaatio- ja sosiaalipsykologinen. Jälkimmäinen lähestymistapa saisi kirjassa mielestäni painottua huomattavasti enemmänkin, jotta täyttyisi tekijöiden lupaus kirjan soveltuvuudesta kaikille organisaation toiminnan kehittämisestä kiinnostuneille (s. 12). Esimerkiksi mentorointia ja hiljaisen tiedon käyttöönottoa sivutaan kirjassa lyhyesti, mutta ohjaukselliset menetelmät johtajuuden osana eivät muuten saa mainittavasti huomiota. Orastavan kotimaisen keskustelun lisäksi ainakin kanadalaisessa yritysmaailmassa aihepiiristä on keskusteltu viime vuosina paljon (Neault 2002).
Aineettoman pääoman käsite ei vaikuta erityisen tarkkarajaiselta, kun tekijöiden mukaan "aineeton pääoma voi olla ihmisestä riippuvaista tai toisaalta riippumatonta, organisaation sisäinen tai ulkoinen voimavara, ostettu tai tuotettu voimavara. Se voi olla yhtä hyvin toimintaa, kuin fyysinen, inhimillinen tai informaatioon perustuva resurssi. Se voi olla myös suoritus tai tulos. Se voi kuvata joko ominaisuntta tai omaisuntta" (s. 19).

\section{Tämän hämmentävän} kuvauksen jälkeen aihepiiri kuitenkin konkretisoituu matkan varrella. Aineettoman pääoman merkityksestä ja arvioinnista organisaatiossa saa kirjassa monitahoisen kuvan lukuisten käytännön esimerkkien avulla. Tekijät muistuttavat toisaalta myös siitä, että aineettomasta pääomasta puhuminen voi olla myös muoti-ilmiö, joka jää helposti organisaatioiden strategiakuvausten korulauseeksi. Myös Ilmonen (2001) kiinnittää huomiota pääoma-sanan myönteisiin konnotaatioihin ja muodikkuuteen.

\section{Ensimmäisessä luvussa}

Rastas ja Einola-Pekkinen esittelevät aineettoman pääoman sisältöä, luonnetta ja merkitystä organisaatiolle. Aineeton pääoma merkitsee osaamista, organisaation tietoa ja aineetonta varallisuutta sekä kolmanneksi vuorovaikutussuhteita, jotka vaikuttavat organisaation kasvuun ja tuloksellisuuteen, mutta eivät kuitenkaan ole organisaation aineellista varallisuutta. Yrityksen resurssit tai volyymien laskeminen ei ole yhtä tärkeää kuin se, mitä yritys tekee näillä resursseilla.
Kirjan jäsennyksen mukaan aineeton pääoma koostuu kolmesta osa-alueesta: inhimillisestä pääomasta sekä rakenne- ja suhdepääomasta. Inhimillisellä pääomalla viitataan yksilöllisiin kykyihin, joilla vastataan annettuihin työtehtäviin. Puhutaan myös osaamispääomasta. Painotus on siten yksilöllisillä kyvyillä, ja herää kysymys, minne ovat kadonneet ne lukuisat tutkimukset, joissa osaamista organisaatiossa on painotettu yksilöllisen sijasta yhteisöllisenä ominaisuutena.

Rakennepääoma merkitsee sitä, että tietoa voidaan siirtää ja ikään kuin rakenteellistaa osaksi organisaatiota yhteisesti hyödynnettäväksi. Rakennepääomaan kuuluvat organisaation prosessi- ja tietorakenteet, joiksi lasketaan mm. tieto- ja viestintäjärjestelmät, menettelytavat ja toimintamallit (kuten käsikirjat, ohjeistot tai laatujärjestelmät) sekä dokumentaatio asiakkaista ja projekteista. Vielä tähän pääoman lajiin lasketaan yritykset strategiat ja tavoitteenasettelut, organisaation kulttuuri sekä organisatoriset rakenteet eli vastuut, jotka määrittelevät asemat ja suhteet organisaatiossa.

\section{Suhdepääomalla tekijät} viittaavat sidosryhmäyhteyksiin kuten asiakkaat, alihankkijat ja toimittajat, palvelun tarjoajat, yhteistyökumppanit ja rahoittajat. Suhdepääoma on se arvo, joka näiden suhteiden kautta luodaan toiminnassa.

\section{Tekijät viittaavat}

lyhyesti myös yllä kuvattuun, yhteiskuntatutkijoiden suosimaan, luottamukseen ja ver- 
kostoihin perustuvan sosiaalisen pääoman käsitteeseen. Tämän pääoman lajin he näkevät vaikuttavan kaikkiin aineettoman pääoman osiin organisaation toiminnan yleisenä edellytyksenä.

\section{Toisessa luvussa}

tarkastellaan organisaation toimintaympäristön kehityssuuntia varsin tavanomaiseen tapaan: kansainvälistyminen, asiakkaiden tarpeiden muutokset, teknologian kehitys, yritysten rakenteellinen järjestäytyminen jne. Tämän jälkeen sukelletaan liikekirjanpidon ja rahoitusmarkkinoiden toimintaan sekä aineettoman pääoman mittaamiseen varsin spesifillä tavalla. Innovaatioista puhuttaessa vedotaan MIT:n kiintoisaan tutkimukseen, jonka mukaan 80 prosenttia innovaatioista syntyy arkisissa keskusteluissa ja ylipäätäänkin vuorovaikutuksessa.

\section{Kolmannessa luvussa}

kuvataan, miten aineeton pääoma näkyy ja vaikuttaa organisaatiossa, so. rakenteissa, strategioissa, johtamisessa, toiminnoissa ja prosesseissa. Lisäksi esitellään joitakin kehittämishankkeita. Case-esimerkeistä saakin varsin elävän kuvan kehittämishankkeiden etenemisestä kuvatuissa organisaatioissa. Toisaalta tietyn kehittämismallin suora soveltaminen muihin organisaatioihin ei kulttuurierojen vuoksi liene sellaisenaan mahdollista.

\section{Organisaation rakenteet tunnetusti joko tukevat tai eivät tue tärkeitä toimintoja. Rakenteiden tulisi mahdollis- taa asioiden mutkaton etene- minen organisaation sisällä sekä suhteissa sidosryhmiin.}

Mikäli näin ei ole, syntyy kirjoittajien mukaan organisaation virallisen rakenteen rinnalle ns. piilorakenne, jota noudatetaan virallisesta organisaatiosta huolimatta.

\section{Neljännessä luvussa}

tekijät hahmottavat prosessikuvausten avulla, miten organisaatio voi kehittää osaamistaan aineettoman pääoman mittaamisessa ja ohjaamisessa. Esiteltävät mallit eivät helposti aukea yritystaloutta tuntemattomalle lukijalle, mutta ne tarjoavat tapauskuvausten tuella alaa hallitseville epäilemättä käyttökelpoisia työvälineitä. Väliotsikon alla "Joukkojen mobilisointi ja toimintasuunnitelma" (sic) Rastas ja Einola-Pekkinen korostavat sitä, että aineettoman pääoman mittaamisessa ja seurannassa tulee keskittyä vain siihen, mitä organisaatiossa täytyy ehdottomasti tietää ja tehdä näkyväksi. Tavoitteet tulee tehdä selkeiksi koko henkilöstölle ja mahdollisesti myös sidosryhmille. Ei ole olemassa yksiselitteistä kaavaa, jonka avulla esimerkiksi oikeat indikaattorit voitaisiin valita. Seurannan ja mittaamisen tapojen tulee istua organisaation kulttuuriin.

\section{Tekijät ovat perehtyneet} aihepiiriinsä tarkoin, mutta runsauden pulan vaikutelmalta on vaikea välttyä. Oppikirjamuodossa lienee vaikea kokonaan välttää vähän paljosta -rakennetta, mutta lukijaystävällisempää olisi ollut selkeä keskittyminen joihinkin lupaavimpiin lähestymistapoihin.

\section{Lähteet}

AHONEN, G. (2000) Henkilöstötilinpäätös organisaation ohjauksen välineenä. Teoksessa Onnismaa, J., Pasanen, H. ja Spangar, T. (toim.) Ohjaus ammattina ja tieteenalana, osa 2. Ohjauksen toimintakentät. Jyväskylä: PS-kustannus.

FINE, B. (2001) Social Capital versus Social Theory. Political Economy and Social Science at the Turn of the Millennium. London and New York: Routledge.

ILMONEN, K. (2000) Sosiaalinen pääoma: käsite ja sen ongelmallisuus. Teoksessa K. Ilmonen (toim.) Sosiaalinen pääoma ja luottamus. Jyväskylä: SoPhi.

KUVAJA, S. (2002) Eettinen foorumi ei saa jämähtää keskustelukerhoksi. Taloussanomat 1. 2 .

LASH, S. (1994) Reflexivity and its Doubles: Structure, Aesthetics, Community. In: Beck, U., Giddens, A. \& Lash, S.: Reflexive Modernization. Politics, Tradition and Aesthetics in the Modern Social Order. Cambridge: Polity Press.

LIITEN, M. (2002) Yritysten arvot puntariin. Helsingin sanomat 17.2., Talous ja työ.

NEAULT R.(2002) Thriving in the New Millennium: Career Management in the Changing World of Work. The Canadian Journal of Career Development / Revue canadienne de développment de carrière. $\mathrm{Vol}$ 1 (1). http://cjcd.contactpoint. ca/v1-n1/article2.pdf

POLANYi, K. (1944) The Great Transformation: The Political and Economic Origins of Our Time. Boston: Beacon Press.

PUTNAM, R. (1993) Making Democracy Work: Civic Traditions in Modern Italy. Princeton: Princeton University Press.

Yrityskulttuuri 2001 -raportti: Lähes kaikki suomalaiset yritykset asettavat toiminnalleen vapaaehtoisia eettisiä normeja [04.12.2001] http://www. kauppakamari.fi/keskuskauppakamari/index.cfm?language $=$ Finnish 